\title{
Political Science B.A. Graduates from the University of Calgary: Education and Career Paths*
}

\author{
Keith Archer*
}

\begin{abstract}
A mailed questionnaire was administered to 199 graduates of the B.A. programme in political science between 1967 and 1985. It was found that (a) most graduates $(63 \%)$ continued studies after graduation, although the proportion who did so increased as rates of unemployment increased; (b) the most popular occupations among graduates were lawyer (22.2\%), manager or consultant $(17 \%)$, teacher (14.8\%) and civil servant (14.8\%), with males more likely than females to be employed in each of these except law; (c) of the four most popular occupations, two (teacher and civil servant) are becoming closed to graduates with cutbacks in the growth of public sector spending; and (d) that the graduate of the $1980 \mathrm{~s}$ is much more flexible both during and after university than were previous graduates. These findings are discussed with reference to the changing employment prospects for political science graduates.
\end{abstract}

\section{RÉSUMÉ}

Une enquête menée auprès de 199 diplômés en science politique qui ont reçu leur diplôme entre 1967 et 1985 a révélé que: (a) la plupart des diplômés (63\%) ont poursuivi leurs études; la proportion de ceux-ci a augmenté lorsque le taux de chômage s'est lui aussi accru; (b) parmi les professions les plus populaires, les diplômés occupaient des postes d'avocat $(22,2 \%)$, de directeur ou de consultant (17\%), de professeur $(14,8 \%)$ et de fonctionnaire $(14,8 \%)$, la plupart, sauf les avocats, étaient des hommes; (c) des quatre professions les plus populaires, deux (professeur et fonctionnaire) devenaient inaccessibles aux diplômés en raison des restrictions budgétaires qui sévissent dans le secteur public; et (d) qu' un diplômé des années 80 est beaucoup plus polyvalent pendant et après ses études universitaires que ne l'étaient ses prédécesseurs. L'article présente une discussion de ces résultats par rapport aux changements dans les perspectives d'emploi des diplômés en science politique. 


\section{Introduction}

A number of recent attempts have been made to track the educational and career paths of social science graduates in Canada (Ralston, 1978; Rennie, 1981). Among the most important findings of these studies is the need for social science graduates to be flexible in their educational and career paths. For example, Rennie (1978: 51) found that 42 percent of psychology graduates from York University residing in Toronto pursued further studies after the B.A. and only 23 percent were employed in "psychotechnology." Likewise, Ralston (1978: 49-51) found that 70 percent of sociology graduates had pursued further education, and that only 30.6 percent were employed in a broad range of fields classified as social welfare.

These studies also suggested that significant gender-based differences were evident in the career paths pursued by graduates. For example, both studies found men more likely to continue studies after the B.A., to be employed in business or management, and for women to be employed as teachers (Ralston, 1978:48-51; Rennie, 1981:51). In addition, Ralston also found a change in the gender composition of the graduating class over time, as the proportion of female graduates increased consistently between 1971 and 1977 .

The present study examines the educational and career paths of Political Science alumni from the University of Calgary between 1967 and 1985. It is an attempt to replicate some of the analyses reported in studies mentioned above as they pertain to a social science department at a western university, and also to go beyond the previous studies by including a larger time frame and examining the effects of changes in rates of unemployment on educational and career paths. We will argue that important changes have occurred in the educational and career paths of graduates over time, and that students will have to be increasingly flexible in charting their paths.

\section{The Sample}

The Department of Political Science at the University of Calgary has been awarding the B.A. degree since 1967. A total of 910 B.A. (Political Science) degrees have been awarded between the Spring convocation of 1967 and the Fall convocation of 1985 . Of these, 833 (92 percent) have been general degrees, 51 (6 percent) have been honours degrees and 26 ( 3 percent) have been with double majors.

As with many departments on campus, Political Science has grown considerably in the period since its founding. For example, as Table 1 illustrates, in the eleven years from 1967 to 1977 , an average of 40 degrees were awarded annually. From 1978 to 1981 the number had increased to 53, and from 1982 to 1985 an average of 67 students graduated annually with the Political Science B.A.

The Office of Alumni Affairs has been reasonably successful in maintaining contact with our graduates, and has a mailing address for 645 ( 71 percent) of them. 
Table 1

Survey Response Rate By Year lof Graduation

Year of

Graduation

Response Rate

\begin{tabular}{llll}
\hline $\begin{array}{l}\text { Number of } \\
\text { Graduates }\end{array}$ & Annual & $\begin{array}{l}\text { Traceable } \\
\text { Graduates }\end{array}$ & $\begin{array}{l}\text { Number of } \\
\text { Respondents }\end{array}$
\end{tabular}

\begin{tabular}{|c|c|c|c|c|}
\hline $1967-1977$ & 434 & 40 & 182 & 62 \\
\hline $1978-1981$ & 210 & 53 & 206 & 66 \\
\hline $1982-1985$ & 266 & 67 & 257 & 69 \\
\hline & 910 & & 645 & $197 *$ \\
\hline
\end{tabular}

* Two respondents did not 1dentify their year of graduation.

As one might expect, the longer the period since graduation, the less likely is contact to be maintained between the university and the graduate. Although the rate of contact is very high for those who graduated between 1982 and 1985 (97 percent) and among 1978-1981 graduates (98 percent), only 42 percent of those who graduated before 1978 have a current mailing address with Alumni Affairs.

Questionnaires were mailed in November 1985 to the 645 individuals for whom the Office of Alumni Affairs supplied a current address, 25 of which were returned undelivered. Of the 620 questionnaires delivered, 199 were completed and returned, providing a response rate of 22 percent of those who have received a Political Science B.A. and 32 percent of those contacted. The data set contains roughly equal numbers of those who graduated between 1967 and 1977 (62), between 1978 and 1981 (66), and 1982 and 1985 (69). (Two respondents did not indicate their year of graduation).

It is difficult with studies of this size and scope to ensure that the results obtained reflect differences in the theoretical population, and are not unique to the particular sample under investigation. There is no method available which allows us to determine definitively whether the sample is valid because we do not have data on all of the characteristics of the theoretical population. However, we can make several comparisons to increase our confidence that the findings reflect real differences among political science graduates. In particular, with a valid sample we would expect that survey respondents have the same residence patterns as all contactable Political Science alumni; that the proportion of honours students in the sample is consistent with the proportion of honours alumni; and that the likelihood of completing a second degree among our respondents is comparable to other studies of this question. 
Among all Political Science alumni, 68.7 percent reside in Calgary, 82.4 percent live in Alberta and 94.8 percent live in Canada. The data are consistent with survey respondents as 63 percent live in Calgary, 80 percent are in Alberta and 96 percent reside in Canada. In addition, two percent of University of Calgary alumni, 2.1 percent of Political Science alumni and 1.5 percent of survey respondents reside in the United States (for further information on all University of Calgary alumni, see Calgary Alumni Magazine, (1986), 6).

In addition to questioning whether the data are biased geographically, one might also wonder whether they are biased qualitatively - that is, whether the "successful" alumni are more likely to respond than are those whose careers after graduation have been less illustrious. Anecdotal evidence would appear to confirm this assumption - indeed, it is conventional wisdom that those whose careers have been most successful are most likely to attend class reunions, alumni banquets and homecoming weekends. Although it is difficult to assess the extent to which this type of bias has affected the sample, the evidence we possess leads us to expect that the bias, if present, is relatively small and consistent with that of similar studies.

If the qualitative bias is present, we would expect honours students to respond at rates significantly higher than general B.A. graduates - the fact of being an honours student indicates superior academic performance. However, in the present sample, honours students were only slightly more likely than general B.A. students to respond to the questionnaire. For example, of the total Political Science B.A. degrees awarded, 5.6 percent were honours degrees, whereas the sample contains 8.5 percent of honours graduates. Thus, the data would suggest that honours students were somewhat more likley to respond, but not at rates which would seriously bias the sample.

In addition, although there appears to be an unusually high proportion of respondents who have pursued advanced studies beyond the B.A. (63 percent), the proportion is consistent with similar studies. For example, Rennie (1981: 48) found that 42 percent of psychology graduates pursued further studies, whereas Ralston (1978: 49) found that 70 percent of sociology graduates enrolled in studies beyond the B.A. It should be noted that one would expect the incidence of further studies to be lowest among the sample of psychology students because the time frame for that study was much shorter than the other two. Rennie administered the questionnaire to 1976-1978 graduates in 1979, providing a maximum three-year interval in which the student could return to school. In contrast, Ralston's study extends for a seven-year period (1971-1977) with questionnaires administered the following year (Ralston, 1978: 49). Thus, many students had a longer time period in which they could enroll in further studies. In the present analysis, the data cover an 18-year period from 1967 to 1985 , providing much of the sample with a very large time frame to return to studies. Furthermore, it is interesting to note that only 47.3 percent of our respondents had or anticipated receiving a second degree four years after graduation, and 50.9 percent had by the fifth year. Thus, although our respondents were more likely than Rennie's to have pursued studies after graduation, most of the difference was due to the much larger time frame of the 
present analysis. These three pieces of evidence combined lead us to conclude that the results of the analysis are not seriously biased.

It also should be noted that there is nothing particularly unusual about the Department of Political Science at the University of Calgary which would distinguish its graduates from those at most other Political Science departments at major Canadian universities. Students may concentrate their studies in the areas of political philosophy, comparative politics, international relations, and Canadian politics, with the latter field including the sub-field of public policy, law and administration (PPLA). Furthermore, students may also receive a Master's degree in PPLA, and this option at both the undergraduate and graduate level may explain in part the high incidence of further study in law. Like most Canadian universities, the population base from which the University of Calgary draws the majority of its students is the immediately surrounding geographical area. Consequently, most of the students have parents employed in the energy or agricultural sectors of the economy. and those interested in private sector employment, and also wishing to remain in the Calgary area, are likely to be employed in, or service, these sectors of the economy. Other than these differences, however, the conclusions drawn from the present analysis should be applicable in other areas of the country also witnessing fluctuations in economic performance and increases in female participation at university and in the workforce.

\section{Education}

One of the most interesting findings of the survey was that for a majority of our alumni, an undergraduate degree was not a terminal degree. Indeed, of the 199 respondents, fully 126 (63 percent) continued their studies beyond the B.A. The two most popular courses of study were towards a professional (mainly law) degree (39 percent) and a master of arts degree (34 percent). An additional 21 percent of second degrees were second undergraduate degrees (mostly in education and business), and a small number decided to obtain a community college diploma.

Not satisfied with two university degrees, a further 14 percent of respondents obtained or are currently studying for a third degree. Of those with a third degree, 41 percent received a Ph.D., 33 percent an M.A., 22 percent a professional degree, and four percent (one student) received a third undergraduate degree. Thus, in total, of the 199 respondents, 55 (28 percent) received a professional degree or are currently enrolled in a professional degree programme (51 of which were law degrees), 52 individuals (26 percent) studied for a Master's degree, 27 (14 percent) pursued another undergraduate degree, 11 (6 percent) studied for a Ph.D., and 5 ( 3 percent) continued their studies at a community college.

Respondents were asked to identify the major reason for pursuing studies subsequent to receiving the B.A. The largest proportion (43 percent) said further study would make them more marketable, followed by those interested in fulfilling career aspirations ( 29 percent), a smaller percentage who wanted to explore further 
a subject of interest ( 23 percent) and finally a small proportion who said they wanted to make more money ( 5 percent).

However, the justification for continuing with studies varied according to the type of degree sought and the field of study. Those who pursued an M.A. or a Ph.D. (mostly in Political Science) did so mainly out of interest in the subject matter. Second undergraduate degrees (mainly in education and commerce) were obtained mainly for increased marketability, and those seeking professional degrees (mainly law) were about evenly split between doing so to fulfill career aspirations and improve personal marketability.

The large number of students mentioning marketability, combined with the conventional wisdom that students remain in school longer during periods of higher unemployment, led us to test the hypothesis that levels of unemployment were related to the likelihood of continuing studies beyond the B.A. Our data allow only a crude test of this hypothesis and should be viewed as suggestive rather than definitive. Nonetheless, the data suggest that length of time since completing the B.A. and rates of unemployment are related to the incidence of further studies.

Regarding the first of these findings, recall that 63 percent of our sample continued studies beyond the B.A. ( 58 percent identified a year of graduation). Of those who graduated between 1967 and 1977, 66 percent have received a second degree or are currently enrolled in a second degree programme, a figure 10 percent greater than those who graduated between 1978 and 1981 (56.1 percent). Among the most recent graduates (1982-1985), 52.5 percent have received a second degree. One of the more obvious reasons those who graduated in the earlier periods were more likely to have received a second degree is that they have had more opportunities for returning to school. When length of time since first degree is controlled, a different pattern emerges, one more consistent with the hypothesis regarding the effect of levels of unemployment on the incidence of further education.

Before examining the unemployment hypothesis, it is necessary to establish a frame of reference on unemployment. Recall that most graduates (66 percent) reside in Calgary after graduation, and 80 percent reside in Alberta. The rate of unemployment in Calgary has been relatively consistent with the province-wide rate since data were collected on the municipality beginning in 1975. For example, in Calgary, unemployment averaged 5.2 percent between 1975 and 1977, 4.3 percent between 1978 and 1981, and 10.8 percent between 1982 and 1985 (Statistics Canada, CANSIM).(1) In Alberta, unemployment was 4.2 percent between 1975 and 1977 (and 4.3 percent between 1967 and 1977), 4.0 percent between 1978 and 1981 , and 10.0 percent from 1982 to 1985 . Thus, using either the municipal or provincial data as reference, we expect the students who graduated in the 1978 to 1981 period least likely and 1982-1985 graduates most likely to have continued studies after the B.A.

When length of time since graduation is held constant, the data conform to our expectations. Among the 1982-1985 graduates, 40.5 percent had received a second degree or anticipated receiving one within three years of graduation, and 
50.6 percent had within four years of graduation. However, among 1978-1981 graduates, only 34.8 percent had received a second degree within three years and 42.4 percent had within four years. Despite these differences, relatively equal proportions of those in each period continued on to the study of law (see below), suggesting that fluctuation tends to occur among the non-professional second degrees. As expected, those who graduated between 1967 and 1977 were in between the two polar groups, with 34 percent receiving a second degree within three years and 46.8 percent within four years. Thus, the data suggest that the rate of unemployment in Calgary and the surrounding area has an important effect on the likelihood of students pursuing further studies beyond the B.A.

\section{Employment}

The employment portrait of Political Science alumni is only partially complete because many graduates currently are enrolled in other degree programmes. Nonetheless, the picture that emerges is complex and varied within a shifting economic environment. Some of the fields which traditionally have been available to Political Science graduates, especially in the public sector, are becoming less open, thereby encouraging our graduates, like those in many other social science departments, to explore employment more aggressively in the private sector.

The data indicate that 69 percent of respondents are employed full-time, 8.5 percent are employed part-time, and 22.6 percent are not employed outside the home. However, of the 45 respondents not presently employed, only three state they are unemployed, whereas 37 (85 percent) are full-time students and 5 (11 percent) are homemakers not seeking employment. In addition, of the 17 respondents employed part-time, three are full-time students, and thus not normally considered unemployed. If we exclude full-time students and homemakers not seeking employment, the data indicate that 89 percent of Political Science alumni are employed full-time, 9 percent are employed part-time, and 2 percent are unemployed and seeking full-time employment.

Our alumni are employed in a wide range of occupations. Among those employed full-time, 43 occupations were mentioned. In Table 2 these have been collapsed to ten categories, and the data are presented separately for men and women.

The data in Table 2 indicate that the legal profession is the most popular among political science graduates. Almost one-quarter of both men and women graduates employed full-time are practicing lawyers, and an additional 21 respondents (11 percent) are presently studying law full-time (data not shown). The next most popular occupation is manager or consultant (both financial and geological), with men somewhat more likely than women to pursue this career. Third and fourth in popularity are occupations as teachers and civil servants. However, unlike Ralston's findings for sociology graduates, men are more likely than women to be teachers, as well as civil servants. The four major fields of employment are followed by a scattering of positions mainly in the private sector including such 
Table 2

\begin{tabular}{|c|c|c|c|}
\hline \multicolumn{4}{|l|}{ Occupation BY Gender } \\
\hline \multirow[t]{2}{*}{ Occupation } & \multicolumn{2}{|c|}{ Gender } & \multirow[b]{2}{*}{ Total } \\
\hline & Men & Women & \\
\hline Lawyer & $22.0 \%$ & $22.6 \%$ & $22.2 \%$ \\
\hline Manager/Consultant & 19.5 & 13.2 & 17.0 \\
\hline Teacher/Professor & 18.3 & 9.4 & 14.8 \\
\hline Civil Servant & 17.1 & 11.3 & 14.8 \\
\hline Sales and Service & 6.1 & 7.6 & 6.6 \\
\hline 011 Industry (general) & 2.4 & 11.3 & 5.9 \\
\hline Communications & 4.9 & 7.5 & 5.9 \\
\hline Secretary/Clerk & 2.4 & 9.4 & 5.2 \\
\hline Self Employed & 4.9 & 3.8 & 4.4 \\
\hline Religion/Health & 2.4 & 3.8 & 3.0 \\
\hline Tota1 & $100 \%$ & $100 \%$ & $100 \%$ \\
\hline $\mathrm{N}=$ & $(82)$ & $(53)$ & (135) \\
\hline
\end{tabular}

fields as sales and service, oil industry (general), communications, secretarial, self-employment and religion/health, with women somewhat more likely than men to engage in each of these fields except self-employment.

A number of interesting trends emerge when occupations are examined over time. Of those who graduated between 1967 and 1977, 25 percent are lawyers, 18 percent are civil servants, and 16 percent teachers. Among 1978-1981 graduates, 31 percent are either practicing lawyers or enrolled in law school, whereas only 5 percent are civil servants and 6 percent teachers. Of those who graduated between 1982 and 1985, 24 percent are practicing lawyers or enrolled in law school, 4 percent are civil servants and 6 percent teachers. Thus, approximately one-quarter to one-third of our graduates have proceeded to the legal profession in each of the groupings. However, there has been a significant decline in the number of graduates employed as civil servants or teachers - occupations which in the past have been amongst the major employers of our graduates. This trend reflects, no doubt, the decline in the demand for teachers as the baby boom has moved fully through the education system as well as the fiscal restraint under which 
governments have managed since the late 1970s, restraint which has been marked by a halt in the growth, and in some cases a real decline, of public sector employment.(2)

\section{The Changing University Experience}

We also were interested in examining various aspects of our alumni's university experience, and how that experience is changing over time. We found, for example, that more than one in five respondents $(22.3$ percent $)$ had been employed full-time before enrolling at the university. Women were significantly more likely than men ( 29.4 percent versus 17.0 percent) to have done so. Interestingly, there has been a significant change over time in the likelihood of having worked full-time prior to entering university. Of those who graduated between 1967 and 1977, only 14.8 percent had worked full-time before university. Among 1978 to 1981 graduates, that figure had increased to 20 percent, and among 1982 to 1985 graduates, fully 30.4 percent had worked full-time before entering university.

Likewise, students are finding the need to be increasingly flexible after entering university, with, for example, larger proportions attending on a part-time basis. Among 1967-1977 graduates, 13 percent attended part-time (for at least some of their education), dropping to 11.0 percent among 1978-1981 graduates and increasing to 18.8 percent among 1982-1985 graduates. Other data also pointed towards greater variety and flexibility of political science graduates in more recent years. It is becoming less common for students to complete a prescribed four year degree programme within four years. Among those who graduated between 1967. and 1977, almost three-quarters ( 74.2 percent) graduated four years after first enrolling at the university. Among 1978-1981 graduates, the proportion had dropped to 65.2 percent and by the 1982-1985 period, less than half (44.9 percent) of the students graduated in four years.

Not surprisingly, in light of the above, more recent graduates were more likely to be older upon graduation than were previous graduates. Among those who graduated between 1967 and 1977, 77 percent were 24 years of age or younger. This figure had increased to 89.3 percent among 1978-1981 graduates whereas in the latest period (1982-1985) only 71.1 percent of graduates were less than 25 years of age upon graduation.

Many of the changes observed over time owe, at least in part, to the changing gender composition of the graduating classes. For example, the proportion of female graduates increased from 24.6 percent between 1973 and 1977 to 34.7 percent between 1978 and 1981, and to 45.5 percent between 1982 and 1985.(3) Compared to their male counterparts, women were more likely to attend university on a part-time basis ( 16.5 percent versus 13.4 percent) to be employed full-time before enrolling ( 29.4 percent versus 17.0 percent) and to be somewhat older upon graduation ( 24.7 years versus 23.3 years).

Women graduates differed from their male counterparts in several other interesting ways. They tended to develop an interest in political science somewhat 
later than men (24.5 percent of women compared to 14.8 percent of men developed an interest in second year university or later), they were more likely to concentrate their studies in political philosophy (the most humanistic of the several areas of the discipline), and they were less likely to pursue studies beyond the B.A. (57.1 percent of women versus 69.0 percent of men).

\section{Discussion}

The data on educational paths suggest that flexibility is the hallmark of university education in the 1980s (see also Rennie, 1981:57). Students are starting university later, staying longer, and are more likely to attend on a part-time basis for at least part of their degree. These changes appear to be due in part to the increasing numbers of women enrolled in the political science programme, and also to the changes in employment prospects as rates of unemployment have varied dramatically during the period covered in the survey.

The data on employment patterns highlight the fact that a Political Science degree is not a vocational degree. Graduates of this department often feel a need to seek further education to enhance their employment prospects. Our graduates increasingly are confronting cutbacks within the public sector and hence will need to pursue avenues of employment within the private sector. Interestingly, both the business community in general, and graduates of the Political Science department, seem to recognize the strengths of a liberal arts education in an increasingly high-technology and communications-based society. For example, a recent survey of businesses undertaken by the University and College Placement Association revealed the widespread feeling that liberal arts graduates are "more flexible and more capable of assuming management positions than graduates of specific areas of study" and that they "have a broader base of knowledge that makes them easy to train and better equipped to transfer their skills within business." (Social Sciences in Canada, 14, April 2, 1986, 10). Our respondents were asked to tell us what good was a Political Science degree. Over half the respondents (53 percent) said they received a better understanding of the world and politics, and more than a third ( 36 percent) said it provided them with tools of analysis. Approximately one-quarter (24 percent) said it provided a stepping stone to subsequent studies or a career, whereas about one-fifth ( 19 percent) said they received a well-rounded education and a similar number ( 18 percent) noted their enhanced communication skills. As the private sector increasingly comes to be seen as possessing the major employment prospects, liberal arts graduates in general, and Political Science graduates in particular, should reinforce and highlight the useful analytic and communication skills obtained through their undergraduate studies. Although these skills will not overcome the major "structural" impediments to an expansion in private sector employment opportunities (see Novek: 1985), nonetheless they will better enable individual graduates to compete in the employment market.

Although the greater flexibility of the university career, and the likelihood of pursuing post-graduate studies, can be applauded as indicative of a more highly 
educated population, they also bespeak the devaluation of both high school diplomas and bachelor degrees. Increasingly, Canadians find it necessary to obtain a bachelor's or advanced university degree in order to enter and maintain their position in the employment market, let alone to advance. However, during a period of fiscal restraint on the part of both federal and provincial governments (see, for example, $\mathrm{Wu}, 1985 \mathrm{a} ; 1985 \mathrm{~b}$ ), coupled with an increasingly senior and more highly paid professoriate (von Zur-Muehlen, 1983), controlling the growth in postsecondary education is emerging as a major policy goal (see, for example, Hardy, 1984).

To the extent that the results of our survey reflect broader trends among social science graduates in Canada, they would suggest that some policy options aimed at reducing education expenditures would be more harmful than others. For example, the data clearly indicate the one of the strengths on a Political Science education, as well as one of the areas in which students see a need for further emphasis, is in teaching students to communicate both orally and in writing. However, if budget restraints lead to larger classroom size, it will become increasingly difficult to conduct classes with a seminar format, and increasingly attractive for instructors to use some form of multiple choice, or other "objective" type of testing procedure. In addition, to the extent that fiscal restraint leads to students being required to contribute a much larger share of the costs of postsecondary education, many students may be unable to afford a university education. Especially hard-hit will be unemployed or underemployed Canadians who wish to obtain a degree as the minimal requirement for employment. In addition, single mothers, and women who wish to obtain a degree to (re)enter the employment market after rearing children, may find increased costs prohibitive.

Cabinet ministers responsible for education policy at both the federal and provincial levels will face difficult choices in the years ahead. Changing employment markets and in female participation rates have led to significant changes in educational paths. These changes bespeak the need for growth in educational expenditure during a time of overall restraint. The situation is further complicated by the overlapping jurisdiction of the federal and provincial governments in postsecondary education policy, a situation in which each level can disclaim responsibility for cutbacks. Such a scenario can place the universities - faculty and students alike - in the middle of federal-provincial conflict, and calls upon universities to help provide creative solutions as we prepare our education system to respond to the challenges of the 1990s and beyond.

\section{NOTES}

* I would like to acknowledge the encouragement and assistance of T.E. Flanagan and the research assistance of Randy Pelletier. The Office of Alumni Affairs and the Office for Institutional Analysis of the University of Calgary provided essential information and assistance. I remain responsible for analyses and interpretations presented herein.

1. Data on monthly rates of unemployment in Calgary have been released by Statistics Canada beginning in January 1975, with comparable provincial and national rates beginning in 1966 . The 
similarity between the Calgary and Alberta provincial rates of unemployment between 1975 and 1985 gives us confidence in inferring that the Alberta rate between 1967 and 1975 can be used as a surrogate for the Calgary rate.

2. The decline in opportunities for public sector employment has had particularly severe effects in Canada because of the unusually large proportions of graduates employed by the government throughout the 1960s and 1970s. For example, Picot (1983: 42-61) notes that 61 percent of Canadian bachelor's graduates in 1976 secured public sector jobs whereas the majority of their American counterparts secured private sector employment (56 percent). Similarly, Novek (1985: 186) notes that, "public services which employ approximately one fifth of the total labour force employed over half of Canadian university graduates while commercial industries which account for approximately three quarters of total employment employed just over 40 percent."

3. Data provided by the Office for Institutional Analysis, the University of Calgary. Data prior to 1973 are unavailable.

\section{REFERENCES}

Calgary Alumni Magazine, 17, 1986.

Hardy, C. The Management of University Cutbacks: Politics, Planning and Participation. Canadian Journal of Higher Education, 14, 1984, 59-69.

Novek, J. University Graduates, Jobs, and University-Industry Linkages. Canadian Public PolicyAnalyse de Politiques, 11, 1985, 180-195.

Picot, W. G. University Graduates and Jobs: Changes during the 1970's. Ottawa: Statistics Canada. Report No. 89-501E. 1983.

Ralston, H. The uses of a Bachelor's Degree in Sociology: Careers of Recent Graduates of a Maritime University. Canadian Journal of Higher Education, 8, 1978, 47-66.

Rennie, D. Survey of York University 1976-78 Bachelor's Degree Graduates in Psychology Located in Greater Toronto. Canadian Journal of Higher Education, 11, 1981, 45-57.

Social Sciences in Canada, 14, April 2, 1986.

Statistics Canada. CANSIM University Base.

von Zur-Muehlen, M. The Changing Profile of Full-Time Faculty at Canadian Universities. Canadian Journal of Higher Education, 13, 1983, 27-40.

Wu, T. Y. S. Federal Contributions to Postsecondary Education Under the Established Programs Financing: Trends and Implications. Canadian Journal of Higher Education, 15, 1985a, 11-23.

Wu, T. Y. S. Provincial Funding of Postsecondary Education Under the Established Programs Financing. Canadian Journal of Higher Education, 15, 1985b, 39-49. 